\title{
MAKING WAR: THE PRESIDENT AND CONGRESS
}

\author{
Graham T. Allison*
}

Consider the implications in each of these vignettes drawn from our nation's history:

The Barbary Pirates. In the summer of 1801 , newly-inaugurated President Thomas Jefferson learned that a declaration of war had been issued against the United States by Tripoli, one of the four kingdoms of the Barbary Coast. Congress was not in session and was not scheduled to reconvene for several months. Jefferson was acutely aware that only the Congress had the power to declare war. What to do?

Jefferson was already familiar with the Barbary situation. For centuries, these states had been running a "protection racket" of sorts against the European nations whose ships plied the Mediterranean's waters: capturing ships, enslaving seamen or holding them for ransom, and exacting tribute from European governments in return for a promise to refrain from such harassment. After United States independence, its ships no longer enjoyed British protection and several were captured. As United States ambassador to France during the $1780 \mathrm{~s}$, Jefferson tried unsuccessfully to secure the release of the crewmen of those ships. Moreover, he attempted to organize a multilateral naval force to police the Mediterranean from such piracy, but to no avail. Having no alternative, the United States thus followed European practice and negotiated treaties with the four Barbary states calling for annual tributary payments.

When Tripoli declared war on the United States, in hope of a higher rate of payment, President Jefferson decided that the United States had had enough. He dispatched four ships of the United States Navy to protect American shipping in the area, but-in the absence of any congressional authorization-ordered them to take only defensive measures. When Congress reconvened that fall, he asked for specific authority to prosecute the war more vigorously, which he promptly received. The combined action of the United States Navy and Marines forced Tripoli to sue for peace in 1805, and by 1830 , the Barbary pirates had been driven from the sea. ${ }^{1}$

\footnotetext{
* Professor of Public Policy, John F. Kennedy School of Government, Harvard University. The author would like to acknowledge the assistance of Richard Huff.

1. See G. Tucker, Dawn like Thunder: The Barbary Wars and the Birth of the U.S. NAVY passim (1963).
} 
War with Mexico. No President added more territory to the United States than James K. Polk. A firm believer in United States expansionism, he tapped latent sources of power within the presidency to achieve his territorial goals, powers that had previously remained untouched-most notably the President's control over the deployment and stationing of United States troops.

In 1845, the United States annexed Texas, despite the strong opposition of Mexico, which had never conceded the independence of its breakaway province. To protect this new acquisition, Polk sent United States troops to defend Texas against a potential Mexican invasion. But the border was illdefined, and as the United States troops advanced into the disputed area, Mexico attempted to repel this alleged invasion of its territory. Polk then used this attack as a pretext for a congressional declaration of war, which he was speedily granted. But many members of Congress were aghast at what they saw as a presidential usurpation of the warmaking power. Former President John Quincy Adams, then a member of the House of Representatives, fumed that Polk's actions had created "an irreversible precedent ... that the President of the United States has but to declare that War exists, with any Nation upon Earth, ... and the War is essentially declared." Adams's colleague, Representative Abraham Lincoln, held similar views: "Allow the President to invade a neighboring nation, whenever he shall deem it necessary to repel an invasion ... and you allow him to make war at pleasure."2

The Cuban Missile Crisis. For thirteen days in October 1962, the United States and the Soviet Union stood "eyeball to eyeball," each with the power of mutual annihilation in hand. The United States was firm but forebearing. The Soviet Union looked hard, blinked twice, and then withdrew without humiliation.

Lincoln had written that "no one man" should have the power to involve the nation in war. Yet in the missile crisis, with the nation on the brink of the most destructive war in history, one man did wield that power, perhaps necessarily so. The demands of the missile crisis-the need for unity, secrecy, flexibility, and dispatch-made congressional consultation impractical. There was time for Congress to pass a resolution authorizing or endorsing whatever actions Kennedy felt necessary to take. Indeed, Congress only two weeks earlier had enacted the Cuban Resolution of 1962, expressing "the determination of the United States to prevent the Marxist-Leninist regime in Cuba, by whatever means may be necessary, including the use of force of arms, from extending its aggressive or subversive activities to any part of the Hemisphere," and "to prevent the creation of an externally supported military capability there endangering United States security." ${ }^{3}$ But there could be only one hand

2. A. Schlesinger. Jr., The Imperial Presidency 41 -42 (1973).

3. Act of Oct. 3, 1962, Pub. L. No. 87-733, 76 Stat. 697. 
on the nuclear trigger. In this instance, command authority over United States forces and decision authority for war or peace were inseparable.

Yet Kennedy did not make his decisions alone. His "ExCom," the group which advised him during the crisis, represented one of the most impressive collections of experience, wisdom, and expertise ever assembled in the White House. No members of Congress were included in the ExCom nor were even asked for their advice. Is it likely that they could have improved upon the array of options presented to the President, options ranging from doing nothing at all to an invasion of Cuba? Could the presence of a few individual members of Congress have conferred the institutional approval of that body upon the President's decision? Although the Constitution assigned to Congress the authority to declare war, technology and time have, it appears, amended the Constitution. Kennedy's ExCom served as a partial equivalent of the constitutional intent.

Vietnam. Arthur Schlesinger, Jr., has written: ${ }^{5}$

Kennedy's action [in the missile crisis], which should have been celebrated as an exception, was instead enshrined as a rule. . . The very brilliance of Kennedy's performance appeared to vindicate the idea that the President must take unto himself the final judgments of war and peace. . . But one of its legacies was the imperial conception of the Presidency that brought the Republic so low in Vietnam.

After a Viet Cong assault on a United States base at Pleiku on February 9, 1965, President Johnson ordered the initiation of regular air strikes against North Vietnam, the beginning of the most intensive aerial bombardment in history. One month later, the first United States combat troops landed in the South, and the country's longest war-already four years old by official estimate-had entered its costliest and bloodiest phase.

Who authorized this undertaking? President Johnson claimed that the responsibility was his alone. The previous August, Congress had passed the Tonkin Gulf Resolution, in which it declared its support for "the determination of the President, as Commander in Chief, to take all necessary measures to repel any armed attack against the forces of the United States and to prevent further aggression." 6 Yet Congress, Johnson claimed, was not delegating its authority in the Resolution, but merely approving the President's actions. "We stated then," he said in 1967, "and we repeat now, we did not think the resolution was necessary to do what we did and what we're doing." his successor. Presidential war reached its zenith during the administration of

\footnotetext{
4. Executive Committee of the National Security Council.

5. A. SChlesinger, JR., supra note 2, at 176.

6. Act of Aug. 10, 1964, Pub. L. No. 88-408, 78 Stat. 384. See also H.R.J. Res. 1145, 88th Cong. 2d Sess., 110 Cong. Rec. 18471,18539 (1964).

7. N.Y. Times, Aug. 19, 1967, at 11, col. 1.
} 
Richard Nixon, who asserted that his constitutional authority as Commander in Chief gave him virtually unlimited discretion over the deployment of United States troops. ${ }^{8}$

In each of these cases, the United States faced the question of whether or not to make war. In each case the nation's decision was affected by many sweeping considerations: the deeper values and current views of the President; values and views of the Congress; the prevailing consensus in the country about the United States' role in international affairs in general; and the merits of the specific case in question. In each case, the decision was also importantly affected by the specific constitutional division of warmaking powers among politically responsible officials, as interpreted by practice, custom, and associated law.

This essay focuses on the last cluster of factors: constitutional and legal arrangements for warmaking. Our purpose is to examine these "constitutional" issues in their concrete political dimensions: identifying effects of alternative divisions of powers, responsibilities, and associated procedures on probabilities of action, and exploring criteria for selecting a preferred division of powers between the President and Congress on this vital issue. The War Powers Resolution of 1973 serves as our central test case.

\section{Constitutional and Political Developments}

The United States Constitution is a product of the eighteenth century. Its authors were men of the Enlightenment and also men of action: political philosophers-mostly at secondhand-with firsthand practical experience. They were intensely conscious of what we have called elsewhere the "paradox of rulership." On the one hand, the common good required that political power be placed in some human hands. Only by yielding considerable discretion to a central public authority could citizens secure the common defense, law, order, or personal liberties. But on the other hand, to establish a powerful public authority was to create enormous risks of the misuse of power. As so often before, the rulers, being human and thus fallible, might choose unwisely, or might implement their choices clumsily, at awful cost. The framers aimed at an effective central government, else they would not have come to Philadelphia. But they sought to minimize the risks.

The product of their work had four distinctive features. One of these was

8. Nixon claimed that the "legal justification" for the invasion of Cambodia, for example, "is the right of the President of the United States under the Constitution to protect the lives of American men .... [A]s Commander in Chief, I had no choice but to act to defend those men." R. Nixon, A New Road for America: Major Policy Statements, March 1970-October 1971, 675,683 (1972).

9. The section that follows draws heavily on Allison \& Neustadt, Afteruord, in R. KenNedy, Thirteen Days; A Memoir of the Cuban Missile Crisis (1971). 
limited authority: the Federal Bill of Rights and its state counterparts were meant to wall off civil liberties, including private property, from arbitrary governmental action. A second feature was shared powers: federal and state governments had overlapping functions, and within the federal structure, so did the President, House of Representatives, Senate, and Supreme Court. A third feature was separated institutions: each power-sharing body had a separate base of political accountability, hence constituency, and these were kept distinct from one another. A fourth feature was legitimation by the symbols of popular sovereignty: the people replaced the monarch, and this was done in such a way as to clothe institutions with their status, while yielding little to direct democracy.

Throughout, the underlying theme was checks and balances; right hedging authority, powers checking powers, separate institutions in enforced collaboration, with political accountability divided and legitimacy dispersed. No one man was entrusted with unlimited prerogatives; neither was the mob. Instead, a goodly group of men, each with a piece of power, backed by a constituency, would scrutinize each other, balancing each other, as they tried to fit their pieces into governance. As Justice Brandeis noted: ${ }^{10}$

The doctrine of the separation of powers was adopted by the Convention of 1787, not to promote efficiency but to preclude the exercise of arbitrary power. The purpose was, not to avoid friction, but, by means of the inevitable friction incident to the distribution of the governmental powers among three departments, to save people from autocracy.

Then as now, the ultimate expression of authority was war, to which this general pattern was applied with special care. The model evidently was the English royal prerogative as modified by Parliament's control over the purse. The framers modified it further. Congress as a substitute for Parliament would also declare war. The Senate as a parliamentary body was to share in making treaties of alliance or of peace. Our President, as substitute for the King, had no prerogative to do these things alone. What he retained, alone, was actual command of such armed forces as congressional enactments gave him leave to raise and keep. Mindful of the problems caused by the Continental Congress's attempts to direct the conduct of the Revolutionary War, the framers sought to protect the President from such harassment. As Alexander Hamilton explained, "[o]f all the cares or concerns of government, the direction of war most peculiarly demands those qualities which distinguish the exercise of power by a single hand."1 But it was the intention of the framers that recourse to war required a collaborative judgment by the whole body of men in national elective office. Presidents could not declare war, congressmen

10. Meyers v. United States, 272 U.S. 52, 293 (1926) (Brandeis, J., dissenting).

11. The Federalist No. 74, at 463 (Lodge ed. 1888) (A. Hamilton). 
could not deploy troops. On this as on all lesser issues, these men were to check and balance one another.

Law must square with reality in order to be effective. Reality is inevitably complex: What constitutes a "war" requiring congressional declaration or authorization? The framers clearly intended that the President be empowered to defend the United States against sudden attack. But the line between defense and offense, never entirely clear at the outset of American history, grew increasingly hazy as the nation's contacts with the outside world proliferated. Virtually from the start of our development under the Constitution, presidents have employed United States military forces abroad to protect our citizens' lives, property, or other interests without declarations of war, and of ten without congressional authorization. By various counts, there have been perhaps as many as two hundred such incidents in United States history. ${ }^{12}$ Moreover, of the conflicts known to us as "wars," three of the four most costly in both lives and money-the Civil War, Korea, and Vietnam-have been undeclared and waged largely on presidential authority, with Congress at best an after-the-fact ratifier of presidential initiatives. Most of these incidents have been small scale affairs, limited in duration, involving few, if any, United States casualties. In many, prior consultation with Congress would have been impractical or impossible, but, unfortunately, no sharp line divided such "incidents" from major wars.

Moreover, the idea that small-scale uses of United States military force (however defined) need no congressional authorization ${ }^{13}$ raises several troublesome issues when one thinks about preferred constitutional and legal processes for making decisions about war. The first is moral: Most of these actions have been directed against the "half-assed nations" of the world, as Senator Goldwater uncharitably described Cambodia during the Mayaguez affair. ${ }^{14}$ But should the United States employ one allocation of warmaking power in its relations with strong nations and quite another with weak ones? ${ }^{15}$

12. E.g., the American Enterprise Institute's analysis of the War Powers Bill lists 161 such incidents. See American Enterprise Institute, The War Powers Bill, Legislative Analysis No. 19, at 47-55 (April 17, 1972). Similarly. J. Terry Emerson, counsel to Senator Barry Goldwater, counts 199, up to and including the Jordanian crisis of 1970. Hearings on S.440 Before the Senate Comm. on Foreign Relations. 93d Cong., Ist Sess. 126-148 (1973) (War Powers Legislation). Among the important were Polk's occupation of the Mexican border territory, Wilson's interventions in Mexico and Siberia, and intervention in the Dominican Republic by no fewer than four presidents.

13. See, e.g., Goldwater, The President's Ability to Protect American's Freedoms-The Warmaking Power, 1971 Law \& Social Order 423.

14. Time, May 26, 1975, at 18.

15. As Professor Henry Steele Commager pointedly asked during the Senate Foreign Relations Committee's hearings on the War Powers Bill:

... [ [I]t is a sobering fact that presidents do not rush in with the weapons of war to bring

Britain, France, Italy, Russia, or Japan to heel. Would we have bombarded Southampton

to collect a debt? Would we have sent an expedition into Rome to protect Americans 
The second issue is legal: If the President is empowered to use military force where the costs, duration, and scope of the action are likely to be limited, what legal restrictions are there on his authority in such cases? May a President legally occupy Botswana or Burundi merely because resistance is likely to be slight: ${ }^{16}$ That question leads to a third, more practical one: If the probable cost of a potential military action is the principle that determines whether congressional authorization is necessary, then how are those costs to be ascertained beforehand? And, more to the point, who is to ascertain them? It is not always clear just how extensive a military conflict will be before the first shots are fired; in fact, it rarely is. Historically, governments have repeatedly embarked on "splendid little wars" only to have them turn into long, drawn-out disasters. The Constitution rests on the assumption that collaborative judgments of the President and Congress will, on the average, produce the most accurate assessments of the probable costs of war and whether they are justified by the potential benefits. If the Congress cannot be persuaded that the United States should engage in military or paramilitary operations in Angola, for example, then one must presume on constitutional principles that it is in fact not in the country's best interest to do so.

The applicability of the constitutional guidelines for the allocation of authority over warmaking has been complicated by yet another factor, the socalled "Lockean prerogative." Locke, the philosophical progenitor of the United States Constitution and intellectual champion of limited government, had acknowledged that in times of dire necessity "the laws themselves should .. . give way to the executive power. . ." 17 This view of the necessity for emergency powers was shared by all of the framers of our Constitution; even Jefferson admitted that "[o]n great occasions every good officer must be ready to risk himself in going beyond the strict line of the law, when the public preservation requires it. . .."18 But while the framers agreed that crisis situations might require that the customary checks upon executive effectiveness be released, they were extremely uncomfortable with the idea, for they

against a threat from a fascist government? Would we have precipitated a war with Britain over a boundary dispute in Maine? Would we land marines in France if customs collectors did not behave themselves: Would we bomb Siberia for years if shots were fired-without any hits-at an American vessel: And does it really comport with the honor and dignity of a great nation to indulge its Chief Executive in one standard of conduct for the strong and another for the weak?

Hearings on S.731, S.J. Res. 18 and S.J. Res. 59 Before the Senate Comm. on Foreign Relations, 92d Cong., lst Sess. 25-26 (1972).

16. As, for example, President Wilson occupied Haiti in 1915. That occupation, which lasted until 1934, was formalized by a treaty ratified by the Senate in February 1916, but the first six months of the occupation were conducted under presidential authority alone. Hearings on $S$. 440, supra note 12 , at 139 .

17. J. Locke, The Second Treatise of Government 81 (1966).

18. Letter from Thomas Jefferson to W.C. Claiborne (Feb. 3, 1807), in The Writings of ThOMAS JefFerson 151 (Mem. ed. 1904). 
were only too aware of the danger that a temporary dictatorship might become a permanent one. As the expanse of government power increased, so did the danger of its abuse.

Lincoln gave us the clearest example of a President's exercise of such emergency authority in our nation's history. Upon taking office in March 1861, he faced the country's gravest crisis. Congress was not in session and was not scheduled to reconvene until the following December; Lincoln immediately called for a special session. But he delayed the opening of that session until July, giving him four months in which to act unilaterally to meet the growing crisis. He ordered a blockade of southern ports, spent public funds without congressional appropriation, expanded the Army and Navy, suspended habeas corpus, and declared martial law throughout the land. These actions, he told that special session of Congress, "whether strictly legal or not, were ventured upon under what appeared to be a popular demand and a public necessity; trusting then as now that Congress would readily ratify them."19 And Congress did ratify them, retroactively authorizing all of his unilateral initiatives. So, too, did the Supreme Court, although in a much more limited way. In the Prize Cases, it upheld Lincoln's unilaterally imposed blockade, finding that the outbreak of war had created a situation to which the President was legally justified in responding "without waiting for Congress to baptize it with a name." ${ }^{20}$ Lincoln himself was uncertain of the legality or constitutionality of his actions. At times he inclined to the view that, though his actions might not be legal, the necessity of the situation justified them; thus he vowed privately that "I will violate the Constitution, if necessary to save the union. . . "21 At other times he asserted that the very necessity legalized those actions; "[M] easures, otherwise unconstitutional," he wrote, "might become lawful, by becoming indispensable to the preservation of the Constitution, through the preservation of the nation." 22 But whatever the legality of his actions, there is no doubt that they were politically legitimate, at least in retrospect, although controversial at the time. After his death, however, Congress reasserted its authority, and the nation entered a period of "congressional government" that was to last until the end of the century. But the questions raised by Lincoln's four years as President remained: What circumstances justified the exercise of such emergency presidential powers? And who was to be the judge? Ultimately, these were political questions of the highest order.

Numerous parallels have been drawn between the presidencies of Abraham Lincoln and John F. Kennedy. Among the more intriguing is the force-

\footnotetext{
19. A. SCHLesinger, JR., supra note 2, at 58.

20. 67 U.S. (2 Black) 635,669 (1863).

21. J. Javits, Who Makes War? 130 (1973).

22. Letter from Abraham Lincoln to Albert Hodges (April 4, 1864), in The Collected Works of Abraham Lincoln 281 (R. Basler ed. 1953).
} 
ful action taken by each on thier own authority to meet grave military threats to the nation. During the Cuban Missile Crisis, Kennedy held the life of the nation in his hands. He was assisted in his ordeal by some of the ablest men of the day, but ultimately, the decision was his alone. Why did Kennedy hold the decision so close to his own chest? The answer is not hard to find: the need to preserve secrecy and flexibility of action, the uncertainty of Soviet intentions, and the extreme complexity of the diplomatic and military maneuvering, and, above all, time or the lack thereof. Taken collectively, these constraints in time limited the circle of men with whom the constitutional Commander in Chief would engage in meaningful consultation. To maximize the prospect of a wise and viable choice, some interests could not be excluded. In the missile crisis the issue was preeminently a matter of defense and diplomacy; it depended throughout on the capability of our intelligence and posed the possibility of military action. As constituted, ExCom assured representation of these interests. Natural parochialism, stemming from the governmental positions of these men, guaranteed that considerations of defense, diplomacy, intelligence, and military action would be voiced. But, potentially, the life of the nation was at stake. How was this interest represented? The President himself represented the nation, with aides of his own choosing, not least his brother, Robert F. Kennedy.

Time made the presidential mind the only source available from which to draw politically legitimated judgments on what, broadly speaking, can be termed the political feasibilities of contemplated action vis-a-vis our world antagonists; judgments on where history was tending, what opponents could stand, what friends would take, what officials would enforce, what men in the street would tolerate-judgments on the balance of support, opposition, and indifference, at home and abroad. As Richard E. Neustadt has observed, "Technology has modified the Constitution: the President, perforce, becomes the only man in the system capable of exercising judgment under the extraordinary limits now imposed by secrecy, complexity, and time." In addition to his traditional roles, the President has become, in Neustadt's terms, "the nation's Final Arbiter.",23

Where was Congress? What about those other minds legitimated by election? They were out of play, except to have their leadership informed at the last moment. Earlier consultation offered nothing indispensable. Congress, to be sure, could add legitimacy, but of this the President conceived he had enough. As a nationally elected officer he was, himself, more representative than all of them together. Besides, command decisions rested constitutionally with his office, not theirs. So he decided first and told them after.

Since the Soviet Union's entry into the nuclear club, the scenario of nu-

23. R. Neustadt, Presidential Power: The Politics of Leadership 212 (2d ed. 1968). 
clear confrontation has dominated most political thinking about the allocation of warmaking authority between the President and Congress. Coupled with the memory of the debilitating effects of congressional isolationism prior to the Second World War, this has allowed postwar presidents a degree of freedom and autonomy over the disposition of United States military forces enjoyed by few presidents before Franklin Roosevelt. Indeed, the belief in executive authority was so strong that when President Eisenhower asked for a congressional resolution endorsing and authorizing whatever military action he might order to defend Formosa, "Mr. Congress" Sam Rayburn feared that the resolution might imply that Eisenhower did not already possess such authority. ${ }^{24}$

Eisenhower also used his executive authority to send several hundred United States military advisers to assist the regime of President Ngo Dinh Diem of South Vietnam; nobody challenged his right to do so. President Kennedy vastly expanded the United States contingent there, and no one questioned his authority either. But after Lyndon Johnson turned this commitment into a full-scale war, the whole ideology of presidential prerogative in military affairs came under increasingly bitter attack.

What Johnson did in Vietnam, he did on his own authority. After sharply escalating the United States' role in the war in the first half of 1965, Johnson could have asked Congress to ratify his policies and to authorize further operations. Though there is little doubt that his request would have been granted, Johnson refused to do so, perhaps fearing to acknowledge publicly that the United States had entered into large-scale hostilities likely to last several years. Johnson did, of course, have the 1964 Tonkin Gulf Resolution in his pocket. Formally, it was a sweeping affirmation of support for whatever the President might choose to do in Southeast Asia; in it, Congress declared that the United States was "prepared, as the President determines, to take all necessary steps, including the use of armed force, to assist any member or protocol state of the Southeast Asia Collective Defense treaty requiring assistance in defense of its freedom."25 Politically, however, it was a flimsy shield. As the scale and intensity of the war steadily expanded, it became increasingly clear that-whatever the Resolution actually said-Congress had not intended for it to be taken quite so literally. In considering it initially, the Senate had rejected an amendment stating that Congress did not endorse "extension of the present conflict"; this followed Senator Fulbright's assurance that such an amendment was needless. ${ }^{26}$ As the war progressed, or failed to, the legitimacy of the Resolution as an expression of congressional sentiment faded.

Once the war had expanded, congressional disillusion was fueled by a feel-

24. A. SChlesinger, JR., supra note 2, at 161 .

25. Act of Aug. 10, 1964, Pub. L. No. 88-408, 78 Stat. 384.

26. See 110 Cong. ReC. 18459 (1964). 
ing of having been duped. Having never committed themselves to war in Vietnam, members of the Senate and House of Representatives felt free to attack "Johnson's war." Attacks by Congressmen helped to legitimate dissent in the country, encouraging others, especially universities and the media. Moreover, the character of congressional criticism gave some credibility to charges that the war was not only senseless and immoral, but also illegal, and therefore illegitimate.

Vietnam's cost, both human and material, and its duration, coupled with the absence of agreed success or even agreed purpose, aroused an opposed perspective to the nuclear-inspired doctrine of presidential prerogative. Through its long and painful history, Vietnam undermined the simple confidence in each of the arguments that had traditionally supported congressional deference to the President in the area of foreign affairs: unity, secrecy, superior expertise, superior sources of information, decision, and dispatch. Indeed, as the Neutrality Acts of the $1930 \mathrm{~s}^{27}$ sapped the self-confidence of Congress about its role in foreign affairs, and discredited congressional control in the eyes of the public, so Vietnam, compounded by Watergate, may have similar effects on the presidency for years to come.

The early 1970s, therefore, saw new impetus behind a search for a functional equivalent of the Constitution's intent-namely, that the body of elected men on Capitol Hill share in White House decisions at the time warfare begins. The power of the purse evidently did not suffice: Witholding funds from forces in the field proved not to be a practicable course for most elected politicians. Congressional search, therefore, focused on ways of giving Congress a voice before those forces got committed beyond recall. From this search emerged the War Powers Resolution of $1973 .^{28}$

II

\section{The War Powers Resolution}

The War Powers Resolution did not leap full-blown from any single mind. Instead, Congress considered a number of alternative proposals of varying scope and intensity for restoring the constitutional balance between Congress and the presidency in warmaking. In the summer of 1973, with United States forces finally withdrawn from Vietnam, each chamber approved its own version of a war powers bill. The Senate bill was most notable in that it attempted to define quite precisely the only circumstances in which a President would be legally authorized to commit United States forces to hostilities in the absence of a declaration of war. These circumstances were:

27. Act of Feb. 21, 1942, ch. 104, 56 Stat. 95; Act of Nov. 17, 1941, ch. 473, 55 Stat. 764; Act of Aug. 27, 1940, ch. 695, 54 Stat. 866; Act of June 26, 1940, ch. 431, 54 Stat. 611; Act of Nov. 4, 1939, ch. 2, 54 Stat. 4; Act of May 1, 1937, ch. 146, 50 Stat. 121: Act of Aug. 31, 1935, ch. 837,49 Stat. 1081 [all codified at scattered sections of 22 U.S.C.].

28. H.R.J. Res. 542, 93d Cong., lst Sess. (1973). 
(1) to repel, retaliate against, or forestall an armed attack on the United States, its territories and possessions;

(2) to repel or forestall an attack on United States troops abroad;

(3) to protect while evacuating, under specific circumstances, United States citizens and nationals whose lives are under direct and imminent threat; or

(4) pursuant to specific statutory authorization.

The Senate bill also required that the war be terminated after thirty days unless Congress voted to continue it, although it did allow the President an additional thirty days to continue the war if "unavoidable military necessity" forced him to do so. ${ }^{29}$

The House version contained no specific delineation of the contingencies that would justify a presidential commitment of United States armed forces into battle. Its time period was 120 days, but it did not allow for a thirty day extension similar to the Senate's bill. It also attempted to strengthen congressional control over the deployment of United States troops overseas, while providing that Congress could terminate the war at any time by concurrent resolution, not subject to veto. ${ }^{3 \prime \prime}$

The final version of the resolution, passed over the veto of President Nixon on November 7, 1973, combined elements of both versions. The Senate's legally binding delineation of the only circumstances to which a President could respond militarily was replaced by a general policy statement without similar force. The President was required to report to Congress within fortyeight hours of the initiation of hostilities on the causes for such action, and to terminate United States involvement unless Congress approved the action within sixty days (allowing him a final thirty day extension). Finally, the conference version required that the President report to Congress on the progress of an undeclared war at least every six months, and that Congress vote to continue or terminate the war within sixty days of each such report. ${ }^{31}$

The War Powers Resolution naturally aroused a good deal of emotion, both pro and con. President Nixon charged that it was "clearly unconstitutional," and that it would "seriously undermine this nation's ability to act decisively and convincingly in times of international crisis." ${ }^{32}$ Gerald Ford complained that it "has the potential for disaster." ${ }_{33}$ Arguing against the bill from the opposite perspective was Senator Eagleton, who believed that the Senate version's legally binding delineation of the President's war powers was the essence of the bill; he called the compromise version a "horrible mistake" that would grant the President "unilateral authority to commit troops anywhere in

29. 119 Cong. Rec. $25119-20$ (1973).

30. Id. at $24655-708$.

31. Act of Nov. 7, 1973, Pub. L. No. 93-148, 87 Stat. 555 [codified at 50 U.S.C. $\$ 1541$ (Supp. IV 1974)]. See also 119 Cong. Rec. 33036-38 (1973).

32. N.Y. Times, Nov. 8, 1973, at 1, col. 8; id. at 20, col. 3 .

33. Id. at 20 , col. 3 
the world for 60 to 90 days." 34 Similarly, Senator Abourezk decried it as "a blank check which will implicate Congress in whatever aggressive warmaking a President judges to be necessary." 35 On the other hand, Senator Javits, who co-sponsored the Senate bill, claimed that "this is a very real, substantive check upon the President so that he must, with any kind of practicality, seek the concurrence of Congress in what we prescribe." 36

Was the War Powers Resolution really "a turning point in the continuing struggle to restore the American constitutional system of checks and balances," as the New York Times editorialized? ${ }^{37}$ Was it the "disaster" that Ford predicted? Or was it a measure with a good deal less significance than both its proponents and its detractors claimed?

\section{III}

\section{Criteria for Evaluation}

On what basis is one to judge constitutional-legal arrangements for warmaking? Focusing specifically on the War Powers Resolution, how is one to decide whether the arrangements it defines for warmaking are to be preferred to the arrangements that preceded passage of the bill, or to other alternative arrangements-for example, a modern-day version of the Ludlow Amendment ${ }^{38}$ that would require a national referendum to declare war or to engage in warfare overseas? Or to take a more current example, what are the merits and possible effects of the proposal recently advanced by Senate aide Michael J. Glennon to attach a statutory funding prohibition to the existing War Powers Resolution in order to deny funding for any activities outside the three conditions set forth in the Resolution's "Purpose and Policy" section?39 What about the resolution drafted by Senator Alan Cranston that would prohibit the first use of nuclear weapons by the United States unless the President obtained the consent of a majority of a committee composed of the Speaker of the House and the Minority Leader, the Majority and Minority Leaders of the Senate, and the Chairmen and ranking minority members of both Armed Services Committees, the Foreign and International Relations

\footnotetext{
34. Id.

35. A. SChlesinger, JR., supra note 2, at 304.

36. 31 CONG. Q. WEEKLY REP. at 2743 (1973).

37. N.Y. Times, Nov. 8, 1973, at 46 , col. 2.

38. 86 Cong. Rec. App. 7058 (1940).

39. Glennon, Strengthing the War Powers Resolution: The Case for Purse-Strings Restrictions, 60

Minn. L. REv. 1. (1975). Section 2(c) of the War Powers Resolution states:

The constitutional powers of the President as Commander-in-Chief to introduce United States Armed Forces into hostilities, or into situations where imminent involvement in hostilities is clearly indicated by the circumstances, are exercised only pursuant to (1) a declaration of war, (2) specific statutory authorization, or (3) a national emergency created by attack upon the United States, its territories or possessions, or its armed forces.
} 
Committees, and the Joint Committee on Atomic Energy?" And what might be the effects of a bill passed early in 1975 by the Senate allowing the President to call up to 50 thousand reservists to active duty for up to ninety days, without a declaration of war or national emergency? While procedures are far from all important, they do have some effect. In trying to evaluate the War Powers Resolution, it is necessary to weigh at least seven clusters of complex considerations.

First, what is the prospect for "good" decisions on war, or the avoidance of war, under the distribution of power and rules of the game envisaged by the Resolution? Does it offer the highest probability among possible alternatives for getting the nation into wars one prefers we enter, and keeping us out of wars one prefers we avoid? Obviously, Americans differ on this issue, some favoring World War II, Korea, and Vietnam alike, some wishing we had stayed out of all three, and many drawing distinctions among them. It is well to recall that in 1812, and again in 1898, Congress rather than the President took the lead in forcing war upon the country. ${ }^{41}$

Second, however one answers the first question "on the average," what about the next case, say, in the Middle East? Under the War Powers Resolution, as compared to other possible alignments of power, what are the prospects for "appropriate" choice? Again, there is obvious disagreement among Americans on what may be appropriate.

Third, how does the Resolution fare as a mechanism for resolving differences among Americans over the decision to enter war? What are its prospects for producing politically viable decisions about war? Is the process for making such important decisions about issues on which the nation may be sharply divided one that most citizens recognize as legitimate?

Fourth, what effects will the Resolution have on the conduct of any given war the United States enters? Will strategy, tactics, and the overall administration of the war be affected by the provisions of the Resolution, and, if so, how?

Fifth, how will the Resolution affect prospects for the termination of war? How will it influence the United States negotiating position? What role will Congress play in the war's conclusion?

Sixth, how will the Resolution affect the overall balance of power between the President and Congress during wars or other military actions?

Finally, what of unintended side effects? These are the bane of constitutional reforms adopted to keep some contemporary problem from ever occurring again. The twentieth amendment is a classic case. In order to avoid forevermore the crisis that ensued in the four months from Franklin Roosevelt's

40. See Federation of American Scientists, Public Interest Report (1975) at 4.

41. J. Javits, supra note 21 , at $56,150$. 
election to inaugural, we so shortened the learning time for presidents-elect as to invite fiascos like the Bay of Pigs.

\section{IV}

The War Powers Resolution in Perspective

The War Powers Resolution was intended to prevent "another Vietnam," at least to the extent that no future President would be able to exercise the kind of unilateral authority that, it was claimed, Presidents Johnson and Nixon had wielded during the course of American involvement in Indochina. But what effect would it have had on United States policy during our last Vietnam? "Historical replays" call for difficult judgments. As a point of departure for broader argument, we offer our judgments-making explicit use of the criteria just listed.

\section{A. Effect on United States Entry into the War}

Would the Resolution have prevented the massive Americanization of the war that occurred in 1965? The answer is a clear no. Despite the popularity of President Johnson's 1964 campaign pledge, that "American boys should not do the fighting for Asian boys," most Americans supported the war effort in 1965. Opposition was confined to relatively small segments of public and congressional opinion, and it seems fairly certain that, if President Johnson had reported to Congress as required by the Resolution shortly after the initiation of sustained United States bombing of the North or the introduction of regular United States combat troops in the South, Congress would have speedily authorized a continuation of the war. (Indeed, as argued above, if he had wanted a formal declaration of war, he would have gotten it.)

\section{B. Effect on Consensus and Legitimacy}

Assuming Johnson had eschewed a formal declaration of war, going the War Powers Resolution route instead, repeated congressional authorizations of the war, long after the Tonkin Gulf Resolution had ceased to command any real respect, would certainly have served to legitimize the war and the decision making process governing it. No longer would it have been so starkly "Johnson's (or Nixon's) war"; Congress would have been on record as a willing accomplice. But it is not at all clear how this process of semiannual reauthorization of the war would have affected public opinion on this divisive issue. On the one hand, with Congress officially "on board," an important forum for legitimizing dissent on the war might have been denied antiwar forces. Congressional complicity in the warmaking process might have stifled congressional dissent; politicians are notoriously reluctant to admit publicly that they have been wrong-repeatedly wrong-on an important issue. It is 
one thing for Senators and Congressmen to admit that they were wrong (or had been deceived) five or six years ago; it is quite another to stand up and say, "I was wrong on this six months ago. Now I'm going to vote differently." Without the vigorous criticism that flowed through the halls of the Capitol, it might have been possible for the administration to isolate dissenters from the mainstream of public opinion, to brand them as unpatriotic extremists.

Yet, opposition to the war sprang far more from its frustrating failure than from its apparent illegality, and it is doubtful that this dissent would have been perpetually stifled by the knowledge that Congress had acquiesced in the war's continuation. Indeed, the requirement that Congress periodically renew its approval for the war might well have provided a focal point for dissent on the war, a target at which antiwar groups could have directed their efforts. These efforts, in addition to the counterefforts of the Administration and its supporters, might have further polarized public opinion on the war instead of creating a consensus.

\section{Effect on the Conduct of the War}

In a very real sense, the Vietnam war was fought out in America's livingrooms. It was America's first televised war, probably the most intensivelyreported war in history. Above all, it was a struggle for the hearts and minds of the people-the American people as well as the Vietnamese. Both sides realized this and planned their strategies accordingly-the communists gambling (successfully, as it turned out) that their staying-power would outweigh American firepower, the Americans churning out reams of statistics purporting to prove that we were somehow winning the war; body counts, targets destroyed, and villages pacified. Rarely has "PR" been such an important military weapon.

Had it been in effect, the War Powers Resolution could only have intensified this "Madison Avenue" aspect of the conduct of the war. American strategy in Vietnam was importantly affected by the presidential campaigns of 1964, 1968, and 1972. According to some reports, John Kennedy had hoped to withdraw from Vietnam after the 1964 elections. When he became President, Lyndon Johnson postponed the sustained bombing of North Vietnam until after he had been elected in his own right. In 1968, Johnson apparently tried to boost the candidacy of Hubert Humphrey by ordering a complete halt to the bombing of the North only a few days before the election. And in 1972, peace suddenly became "at hand" with the election only a few weeks away. The War Powers Resolution would have forced the Administration into tailoring its strategies more closely to the need to obtain congressional approval every six months. It thereby raises the issue of congressional interference in the President's role as Commander in Chief. The Stennis hearings on 
the air war during the summer of 1967-which concluded with the ringing declaration, "It is high time, we believe, to allow the military voice to be heard in connection with the tactical details of military operations." ${ }^{42}$-were at least partially responsible for President Johnson's decision to further escalate the bombing later that year. The Resolution's semiannual reauthorization process might therefore have provided a lever for increased congressional influence over United States tactics and strategy in Vietnam.

It also would have strengthened the argument of those who favored a more rapid escalation of the war against the proponents of the "slow squeeze" approach adopted in 1965. Time was an important factor in the war. In many respects, the American strategy was one of buying time until the South Vietnamese could "hack it." On the other hand, they could not rely on indefinite public and congressional support for the war effort. A War Powers Resolution would have raised the specter that eventually Congress would refuse to renew its authorization for the war in the absence of tangible results, thus strengthening the hand of Administration hawks.

\section{Effect on the War's Termination}

It is interesting to speculate on just when the war would have ended if the War Powers Resolution had been in effect. This would have depended upon how the war had been conducted under the Resolution, the efficacy of the Administration's salesmanship, the willingness or reluctance of Congressmen to reverse their votes on the issue, the effectiveness of antiwar groups in persuading and/or electing Congressmen to vote against the war, and other intangible factors that cannot be weighed with any precision. Yet, given the rising tide of opposition to the war, especially after the Tet offensive of 1968, it is at least arguable that at some point before January 1973, Congress would have refused to renew its approval for the war. This is particularly true since the Resolution would have conferred jurisdiction over the resolutions reauthorizing the war to the Foreign Affairs ${ }^{43}$ and Foreign Relations Committees, bodies that were notably more dovish than the Armed Services and Appropriations Committees that handled the bulk of Vietnam-related legislation.

Had Congress actually gone so far as to declare war on North Vietnam in 1965 , congressional approval would have been required for the peace agreement that terminated that state of war. What would have happened if the Paris agreement had come before the Senate as a treaty? Most likely, it would have been speedily ratified-whatever misgivings individual Senators may have had about the agreement would have been subordinated to their overwhelming desire officially to end the war.

42. 4 The Pentagon Papers 204 (Gravel ed. 1971).

43. Now the International Relations Committee. 


\section{E. Effect on Balance of Power Between the President and Congress}

A war President is a powerful President, and his powers do not stop at the water's edge. Inevitably, the requirements of war enlarge his influence over domestic policy, too. But if Congress is required to give its seal of approval to the war, then those members of Congress who are able to deliver the votes enjoy a potentially vast influence. A legislative leader as powerful as a Rayburn or a Johnson might be able to trade his influence on a war authorization for administration support on his own preferred policies in another realm; an Albert or a Mansfield perhaps less so. Moreover, since the Resolution alters the structure of power within the Congress, providing additional leverage to its more dovish members, the bargaining position of the Congress as a whole may be strengthened. In any event, the need for a President, any President, to bargain continually with Congress in order to gain approval for "his" war may force him to make significant concessions on other fronts and so reduce his unilateral authority.

\section{F. Side Effects}

The principal side effects of the War Powers Resolution on the Vietnam War would seem to be those listed above: pressure for more rapid escalation, effects on dissent from both hawks and doves, possible greater stagemanaging of the war effort in order to win congressional approval. Most importantly, though, the Resolution would have changed the political structure of the debate on the war in this country. The war was a critical factor in presidential politics every four years; and the Resolution would have greatly increased its impact on congressional politics, too. With Congress voting up or down on the war every six months, debate could only have been intensified. Vietnam divided this country as no other issue has in recent memory; under the War Powers Resolution, that fissure would have widened into a chasm.

\section{$\mathrm{V}$}

\section{Speculation About the Future}

Turning from the recent past to the near future, it may be instructive to speculate about the potential effects of the War Powers Resolution on the decision making process in coming situations where the question of United States military intervention arises. Our crystal ball is by no means clear, however, and the following possibilities suggest themselves only as elements of a cloudy future.

One probable effect of the Resolution will be to widen the circle of presidential assistants involved in a decision to use military force and to color the bureaucratic politics from which the decision emerges. Not only national sec- 
urity advisors but also legislative aides, political advisors, and speechwriters will have to be heard by a President contemplating military action because they will be preparing his report to Congress. Moreover, these aides will have grounds for opposing military action without appearing soft or disloyal: whatever the merits, if Congress cannot be persuaded, the viability of the venture will be at risk. A second effect of the Resolution will be to force Congress to act publicly whenever United States troops are engaged in hostilities that last as long as sixty days. This necessity that Congress vote for or against continuation of military action will frame a pervasive public debate about the decision-in Congress, in the press, and on television-a debate whose focus will be shaped by the deadline requiring congressional action within sixty days. A third effect of the Resolution stems from its redistribution of influence within Congress-towards the Foreign Relations and International Relations Committees, who have primary jurisdiction under the Resolution. The character of discussion and hearings in those committees and the nature of resolutions they will report out will be predictably more dovish than analogous discussions and resolutions of committees that authorize and appropriate funds for war. These three effects will create substantial incentives for a President to engage in extensive consultation with Congress before committing United States troops to combat; indeed, if there existed a congressional leadership capable of representing the institution and delivering their colleagues-a significant if -a President would have powerful incentives to engage in meaningful consultation.

Several aspects of the President's response to these factors seem higherconfidence bets. One is that future military actions will be stagemanaged to the fullest extent possible so as to induce a favorable public and congressional reaction. Mayaguez most likely provided a foretaste of things to come: The good news was trumpeted loudly, while the bad new's was dribbled out in small doses; as a result, the Administration's performance was acclaimed a great success, while in fact, in retrospect, it merits no such accolade. Another is that when the President is contemplating military action, two types of military operations will appear much more attractive than any other: those that promise quick victory, within the sixty to ninety days of grace, and those that can become national crusades. For the latter, he will be more likely to seek a formal declaration of war-to avoid the need to return to Congress every six months.

Perhaps the least certain element in assessing the likely impact of the War Powers Resolution concerns the role of Congress: the extent to which Congress will assert its own authority. To date, the record is ambiguous. On the one hand, Congress's cut-off of funding for United States participation in the Angolan conflict reflected a widespread fear of "another Vietnam," however remote. Yet Congress raised no protest to President Ford's evacuations 
of United States and foreign citizens from Phnom Penh and Saigon, and it cheered his handling of the Mayaguez affair-despite the fact that these actions violated seven separate statutory provisions barring the use of funds "to finance military or paramilitary operations by the United States in or over Vietnam, Laos, or Cambodia." 44

The Constitution is, in Professor Corwin's famous phrase, "an invitation to struggle for the privilege of directing American foreign policy." 45 The War Powers Resolution does not alter that basic fact of the political landscape. It may serve as a potential weapon in that ongoing struggle, although for which side is not entirely clear. But the overall "correlation of forces" will be determined by the deeper undercurrents of American political life, among them the "lessons of history" as etched on the popular mind. Before Pearl Harbor, what constrained Franklin Roosevelt was not only, or even mainly, words in statutes, but rather the forbidding strength of isolationist convictions moving millions of his fellow citizens. What fueled their convictions? A deeply held impression that American involvement in the First World War had been a needless waste, a plot for profit. After the war, the freedom, relatively speaking, felt and asserted by successive Presidents reflected not only congressional but also widespread press and public sentiment. What fueled this permissiveness? Above all "Munich" as remembered after victory in World War II. For the foreseeable future, the watchword of American foreign policy will be "avoiding another Vietnam." But whose version of the "lessons" of that conflict will become the prevailing reality? It is an entirely open question, but its answer will largely determine how the "balance" between the President and Congress in warmaking will be struck.

44. The language is taken from section 30 of the Foreign Assistance Act of Dec. 17, 1973. Pub. L. No. 93-189, 87 Stat. 714 [codified at scattered sections of 22 U.S.C. (Supp. IV 1974)]; $c$. Glennon, supra note 39 , at 13 .

45. E. Corwin, The President: Office and Powers 200 (1940). 